\title{
MAP1LC3C wt Allele
}

National Cancer Institute

\section{Source}

National Cancer Institute. MAP1LC3C wt Allele. NCI Thesaurus. Code C116662.

Human MAP1LC3C wild-type allele is located in the vicinity of 1q43 and is approximately 4 $\mathrm{kb}$ in length. This allele, which encodes microtubule-associated proteins $1 \mathrm{~A} / 1 \mathrm{~B}$ light chain $3 \mathrm{C}$ protein, is involved in both autophagy and the regulation of mitochondrial quantity and quality. 